\title{
Histórias da História da Loucura
}

\author{
RICARDO ABÍLIO RAMOS
}

\section{FERRAZ, Maria Cristina Franco (Org.). Três Tempos sobre a História da Loucura. Rio de Janeiro: Relume Dumará, 2001 (Conexões 13).}

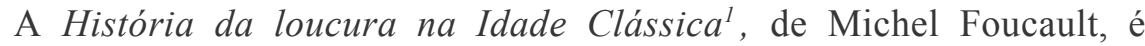
importante referência no entendimento do processo de transformação da loucura em doença mental e de seu encarceramento nos asilos. No entanto, desde o lançamento, em 1961, esse livro tem recebido críticas que ora versam sobre seus dados estatísticos e históricos, ora contestam a proposta do projeto. Uma das críticas mais famosas foi a de Jacques Derrida. Por causa dessas críticas, Foucault, ao reeditar a História da loucura, em 1972, retirou o prefácio da primeira edição (1961) e acrescentou, a título de resposta, dois apêndices, além de escrever um novo prefácio desqualificando nem tanto o prefácio extirpado, mas todos os prefácios de todos os livros.

Lançado recentemente, Três tempos sobre a História da Loucura pretende tornar a polêmica mais acessível ao público brasileiro. Com esse propósito, o livro reúne e traduz três textos: (i) Cogito et historie de la folie $^{2}$ (Cogito e história da loucura) de Derrida, referente à conferência no Colégio de Filosofia, em 1963, e publicado em L'écriture et la différence, em 1967; (ii) Réponse à Derrida (Resposta a Derrida), de Foucault, publicado na revista Paideia, n. 11, em fevereiro de 1972, e que, numa versão revista, com o título de Mon corps, ce papier, ce feu (Meu corpo, este papel, este fogo), foi publicada como segundo apêndice na referida segunda edição da História da loucura; (iii) e Faire justice à Freud: l'historie de la folie à l'âge de la psychanalyse (Fazer justiça a Freud: história da loucura na era da psicanálise) também de Derrida, publicado em comemoração aos 30 anos da publicação da História da loucura, em 19914.

Sendo essa controvérsia, exatamente pela dificuldade de acesso a seus textos fundamentais, ainda pouco conhecida, nos seus detalhes, pelo público brasileiro, o livro organizado por Maria Cristina Franco Ferraz deveria ser saudado como uma oportuna contribuição para o entendimento dos dois autores. A utilidade da coletânea não é só reunir textos até então dispersos, 
mas traduzir, pela primeira vez no Brasil, o texto de Derrida, Cogito e História da loucura, que, numa falha editorial imperdoável, não havia sido incluído na tradução brasileira do Escritura e diferença ${ }^{5}$, (uma edição que, incrementando seu desserviço, omitiu ainda o texto Violence et metaphysique).

Porém, se por um lado, Três tempos sobre a história da loucura facilitou a retomada do debate e o acesso a alguns de seus textos, por outro, há nele uma lacuna significativa: não traz o prefácio retirado por Foucault da primeira edição do seu livro, no qual ele justificava e expunha seus objetivos em escrever a História da loucura, ou seja, um texto fundamental para entender tanto o projeto original da História da loucura quanto as críticas de Derrida.

Além da ausência lamentável de um texto de Foucault, sem dúvida imprescindível, há ainda outros erros na elaboração da edição. Vou mencionar apenas alguns. Na Nota do editor (por que editor, se o livro em sua capa anuncia uma organizadora? Por que quem assina não é $a$ editora? Por que a mudança de gênero? Será que é uma outra pessoa? Quem?). O editor (sic) cita a primeira edição da História da loucura, porém não dá uma palavra sobre o prefácio original, fala da reedição, mas não cita a exclusão desse texto. A ausência do prefácio da primeira edição nem ao menos é citada. Tudo se passa como se esse texto, uma das pedras angulares de todo o debate, fosse irrelevante e negligenciável.

A coletânea repete, assim, o gesto, de certo modo censor, de Foucault, ao retirar seu prefácio da primeira edição e disfarçar sua exclusão com um novo prefácio em tom de radical exprobração a todos os prefácios do mundo. $\mathrm{O}$ editor, ou organizadora, exclui tacitamente um texto fundamental para se compreender a polêmica em sua complexa dinâmica, despotencializando as críticas do texto de Derrida, que nas páginas iniciais de Cogito e história da loucura se referem repetidamente a esse prefácio. Na verdade, o leitor, desavisado quanto à omissão, supondo ter em mãos todos os elementos para compreender o debate, vê-se confrontado com um texto que, como é usual no Derrida de então, é já de difícil entendimento e, ao não dispor desses dados, fica sem saber a que ele afinal está se referindo. Em seguida, ao falar do texto de Derrida, o comentário se restringe apenas à parte de Cogito $e$ história da loucura relativa à forma como Descartes aparece no texto de Foucault - quanto às críticas relativas ao prefácio, nenhuma palavra.

É bastante nítida a posição adotada pelo editor (sic) ao comentar o debate: Foucault, com seu livro, seria "absolutamente inovador, desconcertante 
e inesperado", porém Derrida seria aquele que ficou "marcado pelo peso do discípulo que critica o mestre". Por fim, ao se referir à Resposta de Foucault, ele (ou ela) é ainda mais parcial, dizendo que Foucault veio “(...) derrubar a abordagem derridiana, reduzindo-a a uma 'textualização' e a uma 'pequena pedagogia", ou seja, o editor assume como conclusivo o que não é mais do que o ponto de vista de Foucault.

Em nenhum momento o editor (sic) parece se dar conta de que foi em função das críticas recebidas que Foucault retirou um prefácio de quase dez páginas que apresentava as principais propostas da História da loucura, e pôs outro de apenas duas, além de acrescentar os dois posfácios como resposta. Ora, que críticas foram essas que provocaram tamanha transformação na obra de Foucault? Por que Foucault apenas responde às críticas referentes a sua leitura de Descartes e se cala sobre as críticas ao conteúdo do prefácio extirpado? Estas são questões que inflamam a polêmica. Provavelmente nunca se chegará a uma resposta conclusiva. Em todo caso, o objetivo de uma coletânea é trazer aos leitores a possibilidade de conhecer e buscar se posicionar quanto a ela e não omitir silenciosamente uma parte fundamental da polêmica, induzindo os leitores a um posicionamento partidário a Foucault.

À parte este posicionamento tendencioso, há ainda erros menores nessa Nota do Editor. É, por exemplo, errada a informação de que o texto Resposta a Derrida foi publicado como posfácio na reedição da História da loucura, 1972. Ele fora publicado, meses antes da reedição da História da loucura, na revista Paidéia. Na verdade, foram publicados naquela reedição de 1972 dois textos: La Folie, l'absence d'oeuvre (Loucura, a ausência de obra) e Mon corps, ce papier, ce feu (este uma versão do Resposta a Derrida). Assim, pode-se dizer, fica faltando à coletânea uma introdução mais esclarecedora e honesta, onde estivesse relatada - mesmo que de forma resumida - a cronologia de todos os textos, onde foram publicados originalmente, um resumo dos principais pontos, além de uma pequena bibliografia sobre a polêmica. Outro deslize do editor (sic), corroborando seu descaso com Derrida, é afirmar que Cogito e história da loucura foi publicado na edição brasileira de L'écriture et la différence.

Há outras falhas da revisão editorial, menos importantes, mas que comprovam o pouco cuidado da edição, fazendo com que o livro mereça uma bela página de erratas. Listarei apenas alguns erros. Na ficha catalográfica, o título do livro aparece escrito de modo diferente: Três temas sobre a História da loucura. Ao final da Nota do Editor, o nome do texto de 
Foucault está errado: Respondendo a Derrida.

Além disso, embora o texto Resposta a Derrida já tivesse sido publicado na edição brasileira do Dits et écrits (Ditos e escritos $I)^{6}$ e o tradutor seja o mesmo, comparando-se um texto com o outro, percebemos o seguinte: na página 73, há uma frase onde o erro muda o sentido em relação ao outro texto. Apresento entre colchetes o trecho ou a palavra como está do Ditos e escritos I para que se faça a comparação: "Para Derrida, o que se passou no século XVII não poderia ser senão 'amostra' (ou seja, repetição do idêntico), e não um 'modelo' (...) [ou um "modelo"]. Na página 76: "Mas claro, são loucos (...)" [Mas o que, são loucos (...)]. Aliás, esta frase aparece grafada assim em outros pontos do texto, a saber: p. 80, p. 83. Na página 80: o $E$ no início da frase é verbo e deveria trazer o acento agudo. Na página 81: “dernens” deveria ser demens. Página 83: na frase: “(...) se imaginam ter um corpo de vidro ou ser um jarro", a última palavra aparece na publicação do Ditos e escritos I como moringa $^{7}$. Na página 84 há uma frase com sucessão de erros de acentuação e pontuação que confunde o leitor desavisado ou que não teve contato com o texto de Descartes. Assim, nos Três tempos...: "eu me atacava em princípio, e prudente jamais fiar-se, suponhamos, então, agora", quando deveriam ser três frases distintas: "eu me atacava em princípio", "é prudente jamais fiar-se", "suponhamos, então, agora". Neste caso, a falta de aspas para determinar a separação entre as frases causa confusão, indicando, incorretamente, que é um único período. Quanto ao Fazer justiça a Freud, há novamente a discordância, em alguns termos importantes, em relação à publicação do mesmo texto no livro Foucault: leituras da História da loucura. Assim: a expressão "o grande aprisionamento" (p. 109 e outras) substitui "o grande confinamento"; e a expressão "gênio maligno" (p.110 e outras) substitui agora "gênio astucioso".

Um ponto incoerente com o objetivo de que o livro serviria a um público amplo é não ter havido a preocupação em fazer uma compatibilização das citações e referências com a paginação das edições brasileiras. Inexplicavelmente o livro se refere apenas à edição francesa da História da loucura. A tradução brasileira da História da loucura é bastante difundida, enquanto é raríssima uma biblioteca no Brasil com a edição francesa. Se a proposta do livro é instrumentalizar o debate no âmbito acadêmico nacional e facilitar, por exemplo, que alunos de graduação se ocupem com o tema, é necessário rever todas essas referências. É, assim, também lamentável que o texto Fazer justiça a Freud, repetindo o erro, faça referência nas citações apenas à paginação das edições francesas. 
A meu ver, a omissão tácita do importante Prefácio da primeira edição da História da loucura, a ausência de uma boa e substancial nota introdutória escrita pela organizadora, a falta de referência às traduções brasileiras de Foucault e os inúmeros erros de revisão clamam por uma nova edição dessa coletânea.

\section{NOTAS}

1 Mestre em Saúde Coletiva pelo Instituto de Medicina Social da UERJ.

2 Foucault, M. História da Loucura na Idade Clássica. São Paulo: Perspectiva, 1978.

3 Derrida, J. Cogito et Historie de la folie. In: _. . L'écriture et la différence. Paris: Seuil, 1967 (publicado originalmente na Révue de Métaphysique et de Morale, n. 4, outubro-dezembro 1962)

4 Foucault, M. Mon corps, ce papier, ce feu. In: Folie et déraision. Histoire de la folie à l'âge classique. Paris: Plon, 1972.

5 Derrida, J. Faire justice a Freud: L'historie de la folie à l'âge de la psychanalyse. In: Roudinesco, E. Penser la folie: essais sur Michel Foucault. Paris: Éditions Galilée, 1992. Este texto também está publicado na versão brasileira deste livro, intitulada Foucault: Leituras da história da loucura)

6 Derrida, J. A escritura e a diferença.

7 Motta, M. B. (Org.). Michel Foucault. Problematização do sujeito: psicologia, psiquiatria e psicanálise. Rio de Janeiro: Forense Universitária, 1999 (Coleção Ditos e Escritos I).

8 Jarro e moringa não podem ser considerados sinônimos absolutos. Moringa, segundo o Dicionário Houaiss, é um regionalismo brasileiro, o que pode causar dificuldades a muitos leitores. Jarro teria um sentido mais geral na compreensão da idéia do autor. 